\title{
Cracking susceptibility evaluation of some stone fruit species (Sour cherries - Prunus cerasus L.; Sweet cherries - Prunus avium and European plums - Prunus domestica L.) grown in Hungary
}

\author{
Simon, G., Vágány, É. \& Komma, L. \\ Horticultural Science Faculty, Department of Fruit Science, \\ Corvinus University of Budapest, Villányi út. 29-43.
}

\begin{abstract}
Summary: The rain induced fruit cracking is a big, serious problem especially for sweet cherry growers but in some year growers of other stone fruit species had also problem with fruit cracking caused by too much and heavy rainfalls in the ripening and harvesting season. Cracked stone fruits can be easily infected by different diseases like Monillinia sp. Cracked and infected fruits can not be transported for long distance and using for preservation, they lost their market value by the destroyed fruit quality. It was decided to make a research work to determine the rain fruit cracking susceptibility of few stone fruit species (sour cherries, sweet cherries and European plums). Fruit cracking tests were occurred under laboratory conditions on the most common cultivars grown in Hungary. Furthermore we tried to find correlation between the fruit cracking and some fruit quality parameters (fruit size; total sugar content, fruit flesh firmness).
\end{abstract}

Our conclusions are the followings:

Sour cherries:

There were found differences in the cracking ratio and the cracking dynamics of the tested sour cherry varieties when they were immersed in distillated water for 24 hours. Based on cracking test results under laboratory condition (immersing in distillated water) we made the grouping by cracking susceptibility of sour cherry varieties. Tested cultivars were divided three groups: very susceptible; susceptible; moderately susceptible (tolerant). Groups with varieties are: Very susceptible - 'Maliga emléke', 'Piramis', 'Érdi jubileum','Érdi nagygyümölcsü' and 'Meteor korai; Susceptible (Sensitive) - 'Érdi bőtermő', 'Pándy' and Cigány 59. Moderately susceptible (tolerant) - 'Éva' and 'Petri' as new rereleases.

The most of tested sour cherry varieties are in agreement with the literature (Apostol, 2003) and four of them ('Maliga emléke', 'Pándy 279', 'Éva' and 'Petri') had higher average fruit weight than was mentioned in the literature (Apostol, 2003). Our fruit cracking results are in agreement with Zelinski's (1964) and Christensen's (1975) conclusions that there is no close relationship between fruit size and rain induced fruit cracking tendency.

We found significant differences between the sugar content of tested cultivars. In contrast of Verner \& Blodget (1931) our results confirm Tucker's opinion that the sugar content is not correlation with the cracking tendency of cherry fruits (Tucker, 1934).

Fruits firmness (elasticity) was measured by destructive method when juice was coming out from fruits. There were found big differences of fruit firmness and skin strength of observed cultivars. Our results are only partly agreement with Christensen's (1996) opinion that cherry cultivars with firmer fruits are more prone to fruit cracking than softer ones. By this was seemingly we did not found close relationship between the fruit firmness and the cracking tendency of sour cherry fruits.

We found that during fruits immersing in distillated water the fruit weight was increasing due to the absorbed water. Our opinion is that there is no close relationship between the scale of fruit cracking and the quantity of absorbed water.

By results presented above we our opinion is that no very close relationship between the fruit cracking of sour cherries and the observed parameters (fruit size, fruit firmness, sugar content, amount of absorbed water) maybe other varietal effects and physiological characters (fruit skin structural parameters) play more important role in the fruit cracking mechanism of cherries.

Sweet cherries:

Similarly to sour cherries in the case of sweet cherries we also did not find close relationship between observed fruit parameters and cracking index. It was differences in the cracking ratio and the cracking dynamics of the tested sweet cherry cultivars when they were immersed in distillated water for 24 hours.

It was found that the cracking ratio of very cracking susceptible sour cherry varieties had the same or higher cracking index than observed sweet cherries. It is in contrast with the general opinion (Chistensen, 1996) that sour cherries are less prone to rain induced fruit cracking than sweet cherries.

We found differences between the cracking ration and cracking dynamic of the same cultivar in different years (2006 and 2013 ). It is in agreement Christensen's (1996) opinion that the year effect cause big differences in the fruit cracking of cherries.

European plums

We found differences in the cracking ratio and the cracking dynamics of the tested plum varieties when they were immersed in distillated water for 24 hours. A shorter term (6 hours) immersing in water caused three groups by their cracking susceptibility: „Very susceptible”: 'Révfülöpi' and 'Szarvasi'; ,,Susceptible”: 'Besztercei'; „Less sensitive”: 'Bluefre' and 'Cacanska rodna'. A longer term (24 hours) immersing 
in water resulted only two groups with significant differences: „Susceptible group”: 'Révfülöpi', 'Szarvasi' and 'Besztercei'; „Less sensitive”: 'Bluefre' and 'Cacanska rodna'

Similarly the cherries we did not find correlation between the fruit size and cracking susceptibility of European plum cultivars. It was based on: the big fruit sized 'Bluefre' and middle sized 'Cacanska rodna' cracked in the lowest scale, during the small sized 'Révfülöpi', 'Szarvasi' and 'Besztercei' cultivars cracked in higher scale

We found positive correlations between the cracking susceptibility and total sugar content of tested plum cultivars. Cultivars with significantly lower sugar content ('Bluefre' and 'C. rodna') showed lower fruit cracking susceptibility than cultivars ('Révfülöpi', 'Szarvasi' and 'Besztercei') with higher sugar content).

We found close relationship between the relative (\%) absorbed water amount and the fruit cracking susceptibility. Cultivars with higher absorbed water amount ('Szarvasi'-'Révfülöpi'-'Besztercei') had higher cracking susceptibility.

Keywords: fruit cracking, sour cherry, sweet cherry, European plum

\section{Introduction}

The rain induced fruit cracking is a big, serious problem especially for sour cherry growers but in some year sour cherry growers had also problem with fruit cracking caused by too much rainfall in the harvest season. Earlier in two papers (Simon et al., 2007; Simon, 2006) it was discussed in detailed the reasons and the physiological background of rain induced fruit cracking of sweet and sour cherries. The research work on cherry fruit cracking was supported as a part of a "GAK" project.

\section{Material and methods}

The aim our trial was to determine the susceptibility to rain induced fruit cracking of sour cherry, sweet cherry and European plum market varieties grown in Hungarian. 10 sour cherry cultivars were tested, 8 of them representing the Hungarian commercial variety sort ('Piramis', 'Meteor korai', 'Érdi nagygyümölcsü', 'Érdi jubileum', 'Érdi bőtermő', Maliga emléke', 'Cigány 59' and 'Pándy 279') and 2 new releases (' $T$ ' and ' $R$ ' clones).

Cracking susceptibility of sweet cherries was tested on six cultivars ('Van', 'Germesdorfi óriás, 'Katalin' and 'Kavics') mainly grown in commercial orchards.

In addition 5 European plum varieties were also tested. Three of them ('Besztercei', 'Bluefre' and 'Cacanska Rodna') are well grown in Hungarian plum orchards and two new site selected varieties ('Révfülöpit' and 'Szarvasi').

\section{Short introduction of the tested sour cherry cultivars (Apostol, 2003):}

'Piramis': It is ripening in the firs decade of June few days before cv. 'Meteor korai'. It has large to very large fruit size: the average diameter of fruits is $24-26 \mathrm{~mm}$ and the average fruit weight is $7-8 \mathrm{~g}$. Its fruit quality similar to cv. 'Pándy'. The fruit skin and flesh is dark carmine red and moderately firm, the fruit juice is moderately stainy.

'Meteor korai': It is ripening in the first decade of June. The fruit size is medium: the average fruit diameter is $21-22$ $\mathrm{mm}$, the average fruit weight is $4,5-5,5 \mathrm{~g}$. The fruit shape is fatted round. The fruit skin is dark carmine red and medium thin. The fruit juice is stainy. The taste is balanced, pleasantly sweet-acidic.

'Érdi nagygyümölcsü': It is ripening in the middle of June. The fruit is very large sized, the average fruit diameter is $23-25 \mathrm{~mm}$, and the average fruit weight is around $6 \mathrm{~g}$. The fruit skin is dark carmine red, full ripped is blackish red and medium thin. The fruit flesh is moderately firm and juicy. The taste is pleasantly sweet acidic.

'Érdi bötermö': It ripens between $16^{\text {th }}$ and $20^{\text {th }}$ of June. The fruit is medium sized with $21-23 \mathrm{~mm}$ diameter and the average fruit weight is $5,6-6,0 \mathrm{~g}$. The fruit shape is regularly rounded. The fruit flesh is moderately firm, dark red and the fruit juice is moderately stainy. The taste is pleasantly sweet acidic.

'Érdi jubileum': It has elongated ripening season from the beginning of June. It has regular rounded fruit shape. The fruit is medium sized with $21-23 \mathrm{~mm}$ diameter and the average fruit weight is $7,7-5,9 \mathrm{~g}$. The colour of the fruit is depending on the maturity status carmine red to blackish red. The fruit flesh is very firm. The soluble solid content of fruits is high (at the beginning of the ripening the refraction is $12-13 \%$, in full ripped status it can rich 22-23 ref.\%.

'Maliga emléke:' Its ripening season starting around $20^{\text {th }}$ of June. The fruit shape is fatted round. Fruits are very large sized, $23-25 \mathrm{~mm}$ diameter and fruit weight is $6,5-7,5$. The fruit flesh is moderately firm, the fruit juice weak of colour. The taste is acidic sweet.

Cigánymeggy 59: Fruits are small sized with 18-20 diameters and $4 \mathrm{~g}$ fruit weight. The fruit flesh is moderately firm and dark blackish purple coloured, and the fruit juice is stainy. The soluble solid and acid and sugar content are also high.

Pándy 279: This numbered clone has better fruit quality and grooving parameters than the basic cultivar. It is ripening in the end of June. The fruit size is middle large to large (diameter is $24-25 \mathrm{~mm}$ and fruit weight is $5-6 \mathrm{~g}$ ) depending the crop load. The fruit flesh is dark red and moderately firm. The fruit juice is coloured slightly. Its taste is typical, acidicsweet. 
The tested two new releases by site selection from NorthEast part of Hungary:

'Éva' (earlier called as “T”'-clone: It was selected by Ferenc Szőke around Fényeslitke. It ripens in the beginning of June. In its appearance and fruit parameters is similar to the "Újfehértói fürtös". Fruits size is medium large (diameter is about $21,8 \mathrm{~mm}$ and the average fruit weight is $5,3 \mathrm{~g}$ ). The fruit flesh is firm and the fruit juice is moderately stainy. The sugar content is lower than the case of cv. 'Újfehértói fürtös' .

'Petri' (earlier called as " $R$ "-clone): It was selected by Ferenc Szőke around Lövőpetri. It is late ripening variety; the ripening season is in the beginning of July. The fruits are middle sized with $21,5 \mathrm{~mm}$ diameter and the average fruit weight is $5-5,5 \mathrm{~g}$. Fruit skin is shiny red. The fruit flesh is firm with pleasure acidic-sweet taste. The fruit juice is moderately stainy.

\section{Short introduction of the tested sweet cherry cultivars (Apostol,2003; Tóth, 2001; Tóth and Simon 2009)}

'Van' Is a Canadian origin hard fleshed sweet cherry cultivar. It has a middle fruit size (4-8g fruit weight with 22-24 $\mathrm{mm}$ fruit diameter. Tree has a moderate vigour, extremely good yielding. It can be used for fresh market and processing too. Less prone to rain induced fruit cracking.

'Germersdorfi óriás' is a traditional hard fleshed Hungarian cherry variety. It has big fruit size (average fruit weight 6-9 $\mathrm{g}$ and fruit diameter is $24-27 \mathrm{~mm}$ ). It can be used for fresh market, export and canning too. Tree has a strong vigour and only middle yielding. Sensible to fruit cracking.

'Katalin' is a late ripening 'Germersdorfi type hard fleshed „Brózik-hybrid. It can be used for fresh market and processing (canning and deep freezing) too. The average fruit weight is $9-11 \mathrm{~g}$ and the fruit diameter is $25-28 \mathrm{~mm}$. Tree has a moderate strong vigour and good yielding.

'Kavics' is a Hungarian origin hybrid cultivar. It has a middle fruit size (average fruit weight 6-7 $\mathrm{g}$ and fruit diameter is $24-25 \mathrm{~mm}$ ). The fruit flesh is extremely hard like "pebble stone". Fruit and juice colour is intensive and dark. It can be used for processing and deep freezing. The tree has a strong vigour with an upright canopy, good yielding.

\section{Short introduction of the tested European plum cultivars} (Szabó, 1997; Szabó, 2003, 2004; Soltész, 1998; BrózikKállay, 2001; Tóth-Surányi-Erdös, 2005)

'Cacanska rodna': It is originated from hybridization of 'Besztercei' and 'Stanley' cultivars. It is good yielding cultivar, ripening in the middle of August can be used for fresh market and processing too. Fruits are freestone and middle sized (30-35 g). Fruit shape is elongated with $30-34 \mathrm{~mm}$ diameter. Fruit skin is dark blue and strongly bloomy. Fruit flesh is yellow, firm, and juicy with pleasant sweet taste.

'Besztercei': Its history looks back many hundred years in the Carpathian basin. 'Besztercei' is one of the most important plum varieties in Central Europe. It is ripening at the beginning of September. Due to its outstanding fruit param- eters it can be used for any kind of consumption, for fresh market, for deep freezing, for canning too. Fruits are small sized $(15-20 \mathrm{~g})$ with elongated shape $(28-30 \mathrm{~mm}$ diameter). The fruit skin is dark blue and strongly bloomy. Fruits flesh is yellow-green, firm, juicy and with balanced sweet - acidic spicy taste.

'Bluefre': It is from hybridization of 'Stanley' and 'President' cultivars. It is ripening at the beginning of September. Mainly it is used for fresh market, but harvested in full ripped status fruits can be used for making dried plums. It has really big fruit size $(45-60 \mathrm{~g})$ with $40-44 \mathrm{~mm}$ diameter. Fruit shape is ellipsoid and often asymmetrical. The fruit skin is dark blue and strongly bloomy. Fruit flesh is green-yellow, firm and fruit

'Révfülöpi': It was found around the Lake Balaton as a free pollinated seedling. It is ripening in the middle of August and good yielding. Fruits are middle sized (22-26 g), elongated shaped and fruit skin is dark blue and bloomy. Fruit flesh is green-yellow; firm and juicy; freestone. The main fruit parameters are: $12-18 \%$ refr., invert sugar content $11-14 \%$ and acid content is $1,2-1,4 \%$.

'Szarvasi': It is an origin unknown variety, maybe it was a seedling. It is ripening in the second part of August. Fruits are middle sized (23-26 g), elongated shaped and fruit skin is dark blue and moderated bloomy. Fruit flesh is orangeyellow, moderately firm, juicy and spicy taste, freestone. Typically parameters of fruits are: 16-19\% refr., invert sugar content $9-12 \%$ and acid content is $0,5-0,7 \%$.

Samples of sour cherry varieties were collected in ÉrdEvíra from orchards of Fruit and Ornamental Research Institute. Sampling times are shown in Table 1.

Tested European plum fruits were harvested in Agárd in orchards of Agárd-Frucht Ltd. In the sampling time plum fruits were ready for fresh market with $90 \%$ ripening status. Fruits of 'Révfülöpi', 'Cacanska rodna' and 'Szarvasi' cultivars were harvested at 20-25. August in 2006. Fruit samples of 'Besztercei' and 'Bluefre' varieties were picked in $4^{\text {th }}$ and $5^{\text {th }}$ of September in 2006. Laboratory tests were done at Fruit Quality Testing Laboratory of Fruit Science Department of Corvinus University of Budapest.

Table 1: The sampling times of the tested sour cherry varieties in 2006

\begin{tabular}{|l|c|}
\hline \multicolumn{1}{|c|}{ Cultivar / variety } & $\begin{array}{c}\text { Sampling time of fruits at } \\
\mathbf{8 5 - 9 0 \%} \text { ripening status }\end{array}$ \\
\hline 'Piramis' & 2006.06 .02$. \\
\hline 'Meteor korai' & 2006.06 .02$. \\
\hline 'Érdi nagygyümölcsü' & 2006.06 .07$. \\
\hline 'Érdi jubileum' & 2006.06 .07$. \\
\hline 'Érdi bőtermö' & 2006.06 .22$. \\
\hline 'Maliga emléke' & 2006.06 .22$. \\
\hline 'Cigány 59' & 2006.06 .27$. \\
\hline 'Pándy 279' & 2006.06 .29$. \\
\hline "T'-clone & 2006.06 .03$. \\
\hline „R'-clone & 2006.06 .03$. \\
\hline
\end{tabular}




\section{Measurements of sour cherries:}

To measure firmness and skin strength a "QB-129" -type fruit examinator was used on 10 fruits repeated 3 times (data of firmness are in $\mathrm{Kp} / \mathrm{cm}^{2}$ ). The refr.\% on 10 fruits repeated 3 times with an "ATAGO PAL-1" type digital refractometer (refr.\% is in Brix\%). In each variety sample it was measured the weight of 100 fruits and the same 100 fruits were immersed in distillated water. After 2, 4, 6, 8, 10, 12, 18, 24 hours the cracked fruits were counted and the cracking ratio were calculated and the total weight of 100 fruits was also measured in the same times.

\section{Measurements of sweet cherries:}

We are presenting data of sweet cherries measured in different years ('Van' - data are presented in average four years 1995-1998; 'Germersdorfi óriás' - data are presented in average four years 1995-1998 and data from 2006; 'Kavics' 2006; 'Katalin' - 2006, 2013). From 1995-to 1998 year by year it were measured firmness and skin strength a "QB-129" -type fruit examinator was used on 10 fruits repeated 3 times (data of firmness are in $\mathrm{Kp} / \mathrm{cm}^{2}$ ). The refr.\% on 10 fruits repeated 3 times with an "ATAGO PAL-1" type digital refractometer (refr.\% is in Brix\%). In each variety sample it was measured the weight of 100 fruits and the same 100 fruits were immersed in distillated water. After 4, 24 hours the cracked fruits were counted and the cracking ratio were calculated.

Only fruit cracking index $(\%)$ data are presented from 2006 and 2012 years

\section{Measurements of European plums:}

To measure firmness and skin strength"QB-129" -type fruit examinator was used on 10 fruits (data of firmness are in $\mathrm{Kp} / \mathrm{cm}^{2}$ ). The refr.\% on 10 fruits with an "ATAGO PAL-1" type digital refractometer (refr.\% is in Brix\%). In the case of each plum cultivars it was measured the weight of 10 fruits and the average fruit weight was calculated. By cultivars it were 10 plum fruits repeated 4 times $(4 \times 10$ fruits) immersed in distillated water. After 2, 4, 6, 8, 10, 14, 24 hours the cracked fruits were counted and the cracking ratio were calculated and the total weight of 10 fruit samples repeated forth were also measured in the same times.

Collected and counted data were stored and designed by Microsoft Excels software. Averages and One-way variance analysis were done and different homogenous groups were signed with different letters.

\section{Results, discussion an conclusions}

\section{Sour cherries}

Fruit cracking tests of sour cherry cultivars under laboratory conditions (fruits were immersed in distillated water): There were found differences in the cracking ratio and the cracking dynamics of the tested sour cherry varieties when they were immersed in distillated water for 24 hours (data are shown in Table 2 and Figure 1).

Table 2: Cracking susceptibility (cracking ratio in \%) of the tested sour cherry cultivars in $85-90 \%$ maturity status according to immersing time in distillated water (2006)

\begin{tabular}{|c|c|c|c|c|c|c|c|c|c|c|}
\hline & $\begin{array}{c}\text { Meteor } \\
\text { korai }\end{array}$ & Piramis & $\begin{array}{l}\text { Maliga } \\
\text { emléke }\end{array}$ & $\begin{array}{c}\text { Érdi } \\
\text { bötermő }\end{array}$ & Cigány 59 & Pándy 279 & $\begin{array}{c}\text { Érdi } \\
\text { jubileum }\end{array}$ & $\begin{array}{c}\begin{array}{c}\text { Érdi } \\
\text { nagy- } \\
\text { gyümölcsü }\end{array} \\
\end{array}$ & T-clone & R-clone \\
\hline 0 hour & 0 & 0 & 0 & 0 & 0 & 0 & 0 & 0 & 0 & 0 \\
\hline 2 hours & 1,7 & 24,6 & 7,5 & 0,0 & 0,0 & 0,0 & 0,0 & 10,0 & 0,0 & 0,0 \\
\hline 4 hours & 5,1 & 37,3 & 19,2 & 0,0 & 0,8 & 0,0 & 6,7 & 20,0 & 0,8 & 0,0 \\
\hline 6 hours & 10,2 & 54,2 & 55,0 & 3,3 & 3,3 & 0,0 & 16,7 & 34,2 & 0,8 & 0,0 \\
\hline 8 hours & 20,3 & 62,7 & 71,7 & 4,2 & 4,2 & 0,0 & 34,2 & 50,0 & 0,8 & 0,0 \\
\hline 10 hours & 33,1 & 72,0 & 76,7 & 11,7 & 5,8 & 6,7 & 40,0 & 54,2 & 0,8 & 0,0 \\
\hline 12 hours & 47,5 & 83,9 & 82,5 & 23,3 & 12,5 & 15,8 & 49,2 & 59,2 & 0,8 & 0,8 \\
\hline 18 hours & 75,4 & 89,8 & 91,7 & 44,2 & 33,3 & 34,2 & 84,2 & 79,2 & 2,5 & 1,7 \\
\hline 24 hours & 82,2 & 96,6 & 96,7 & 66,7 & 45,0 & 55,0 & 91,7 & 87,5 & 3,3 & 1,7 \\
\hline
\end{tabular}

Table 3: Grade of the tested fresh market ready sour cherry cultivars by cracking susceptibility (cracking ratio in \%) according to immersing time in distillated water (2006)

\begin{tabular}{|c|c|c|c|c|c|c|c|c|c|c|}
\hline \multirow{2}{*}{ Time } & \multicolumn{10}{|c|}{ Ranks } \\
\hline & 1. & 2. & 3. & 4. & 5. & 6. & 7. & 8. & 9. & 10. \\
\hline 12 hours & Piramis & $\begin{array}{l}\text { Maliga } \\
\text { emléke }\end{array}$ & $\begin{array}{l}\text { Érdi } \\
\text { nagygy- } \\
\text { ümölcsü }\end{array}$ & $\begin{array}{l}\text { Érdi jubí- } \\
\text { leum }\end{array}$ & $\begin{array}{l}\text { Meteor } \\
\text { korai }\end{array}$ & $\begin{array}{l}\text { Érdi bő- } \\
\text { termő }\end{array}$ & Pándy 279 & Cigány 59 & T-clone & R-clone \\
\hline 24 hours & $\begin{array}{l}\text { Maliga } \\
\text { emléke }\end{array}$ & Piramis & $\begin{array}{l}\text { Érdi jubí- } \\
\text { leum }\end{array}$ & $\begin{array}{l}\text { Érdi } \\
\text { nagygy- } \\
\text { ümölcsű }\end{array}$ & $\begin{array}{l}\text { Meteor } \\
\text { korai }\end{array}$ & $\begin{array}{l}\text { Érdi bő- } \\
\text { termő }\end{array}$ & Pándy 279 & Cigány 59 & T-clone & R-clone \\
\hline
\end{tabular}

*Note: 1 - the most susceptible; 8 - the least susceptible 


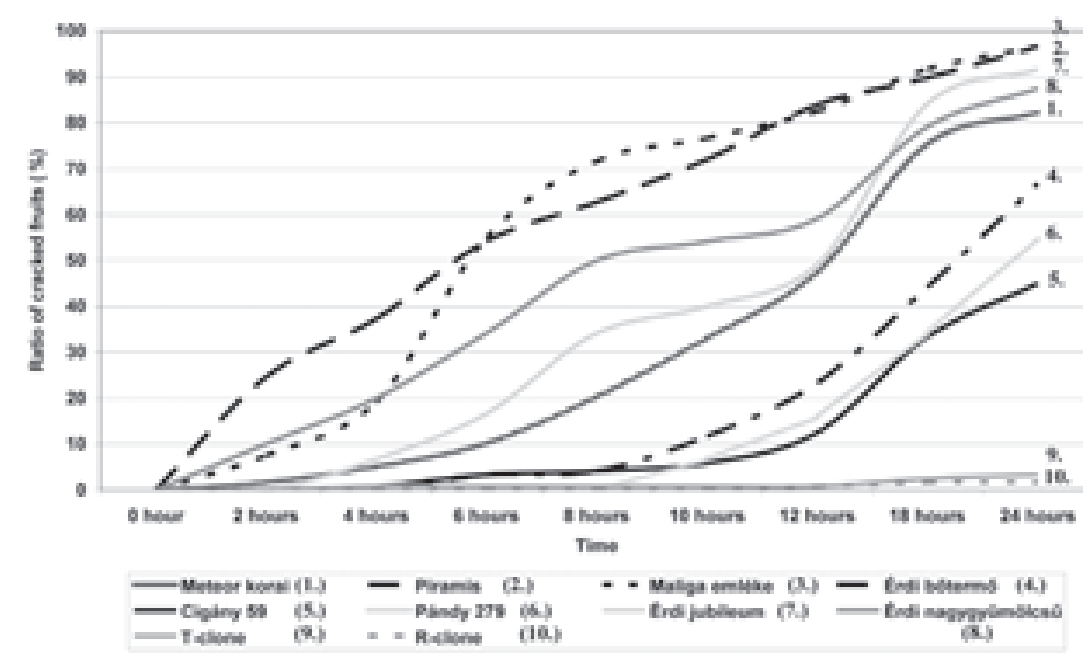

Figure 1: Cracking susceptibility (cracking ratio in \%) of the tested sour cherry cultivars in 85$90 \%$ maturity status according to immersing time in distillated water (2006).

By the cracking susceptibility of tested sour cherry varieties in $85-90 \%$ maturity status immersed in distillated water for 12 and 24 hours were ranking, data shown in Table 3.

Based on cracking test results under laboratory condition (immersing in distillated water) we made the grouping by cracking susceptibility of sour cherry varieties. Tested cultivars were divided three groups: very susceptible; susceptible; moderately susceptible (tolerant). Groups with varieties are shown in Table 4.

Table 4: Grouping of tested sour cherry varieties by fruit cracking tendency under laboratory condition (immersing in distillated water) (2006)

\begin{tabular}{|c|c|c|}
\hline Very susceptible & $\begin{array}{c}\text { Susceptible } \\
\text { (Sensitive) }\end{array}$ & $\begin{array}{c}\text { Moderately } \\
\text { susceptible (tolerant) }\end{array}$ \\
\hline $\begin{array}{l}\text { 'Maliga emléke', } \\
\text { 'Piramis', } \\
\text { 'Érdi jubileum', } \\
\text { 'Érdi nagygyümölcsü' } \\
\text { and } \\
\text { 'Meteor korai' }\end{array}$ & $\begin{array}{l}\text { 'Érdi bőtermő', } \\
\text { 'Pándy' and } \\
\text { Cigány } 59 .\end{array}$ & $\begin{array}{l}\text { "T" and „R" clones } \\
\text { as new releseases }\end{array}$ \\
\hline
\end{tabular}

Table 5: The average fruit weights of the tested sour cherry cultivars related data in the literature (Érd -Elvíra, Újfehértó, 2006.)

\begin{tabular}{|l|c|c|}
\hline \multicolumn{1}{|c|}{ Cultivar } & $\begin{array}{c}\text { The average fruit } \\
\text { weight in the test } \\
\text { orchards (g) }\end{array}$ & $\begin{array}{c}\text { The average fruit } \\
\text { weight in the litera- } \\
\text { ture* (g) }\end{array}$ \\
\hline 'Maliga emléke' & 8,4 & $6,5-7,5$ \\
\hline 'Piramis' & 7,1 & $7,0-8,0$ \\
\hline 'Pándy 279' & 6,5 & $5,0-6,0$ \\
\hline „R'-clone & 6,1 & $5-5,5$ \\
\hline „T'-clone & 6,0 & 5,3 \\
\hline 'Érdi nagygyümölcsü' & 5,1 & 6,0 \\
\hline 'Érdi bőtermö' & 5,0 & $5,6-6,0$ \\
\hline 'Meteor korai' & 4,5 & $4,5-5,5$ \\
\hline 'Érdi jubileum' & 4,1 & $4,7-5,9$ \\
\hline 'Cigány 59' & 3,3 & 4,0 \\
\hline
\end{tabular}

* (Apostol, 2003)
The average fruit weight: The average fruit weight: In four cases of tested sour cherry cultivars ('Érdi nagygyümölcsü', 'Érdi bőtermő', 'Érdi jubileum' és 'Cigány $59^{\prime}$ - cells signed with gray background in Table 3) the average fruit weight was lower than fruit weight mentioned in the literature (Apostol, 2003). The reason could be that we sampling the fruits in $85-90 \%$ ripening status when in the orchards the harvesting is usually beginning not in full ripped status. In the case of the other six varieties are in agreement with the literature (Apostol, 2003) and four of them ('Maliga emléke', 'Pándy 279', „R"-clone, „T"-clone) had higher average fruit weight than was mentioned in the literature (Apostol, 2003.; Table 5).

Based on our results we can not support Tucker's (1934) and Sekse's (1987) opinions that bigger fruits are prone to cracking more. In our trial there were varieties (Pándy 279, R” and „T”-clones) with bigger fruit size and cracked less proportion than cultivars with smaller fruit size. It was also found that varieties ('Maliga emléke' and 'Piramis') with big fruit size had high cracking susceptibility. It seems our results are in agreement with Zelinski's (1964) and Christensen's (1975) conclusions that there is no close relationship between fruit size and rain induced fruit cracking tendency.

Sugar content of sour cherries: By statistical analysis we found significant differences between the sugar content of tested cultivars (Table 6 and Figure 2). By the result of statistical analysis tested sour cherry cultivars were divided in three groups by their sugar content (Table 6).

Table 6: Grouping of tested sour cherry cultivars by the sugar content (2006)

\begin{tabular}{|c|c|c|c|}
\hline Cultivars & $\begin{array}{c}\text { Sugar } \\
\text { content - Brix } \\
\%\end{array}$ & $\begin{array}{l}\text { Homogene } \\
\text { groups }\end{array}$ & $\begin{array}{c}\text { Sugar } \\
\text { content group }\end{array}$ \\
\hline $\begin{array}{l}\text { 'Érdi nagy- } \\
\text { gyümölcsű' }\end{array}$ & 12,5 & $\mathrm{a}$ & \multirow{4}{*}{$\begin{array}{l}\text { Cultivars with } \\
\text { low sugar } \\
\text { content }\end{array}$} \\
\hline 'Meteor korai' & 13,2 & $\mathrm{ab}$ & \\
\hline 'Piramis' & 13,6 & $\mathrm{bc}$ & \\
\hline 'Érdi bőtermő' & 13,7 & $\mathrm{bc}$ & \\
\hline 'T-clone' & 14,3 & $\mathrm{c}$ & \multirow{4}{*}{$\begin{array}{l}\text { Cultivars with } \\
\text { middle sugar } \\
\text { content }\end{array}$} \\
\hline 'R-clone' & 15,1 & $\mathrm{~d}$ & \\
\hline ‘Érd jubileum’ & 15,2 & d & \\
\hline 'Pándy 279' & 15,2 & d & \\
\hline 'Maliga emléke' & 16,2 & $\mathrm{e}$ & \multirow{2}{*}{$\begin{array}{l}\text { Cultivars with } \\
\text { high sugar } \\
\text { content }\end{array}$} \\
\hline ‘Cigány 59’ & 19,1 & $\mathrm{f}$ & \\
\hline
\end{tabular}




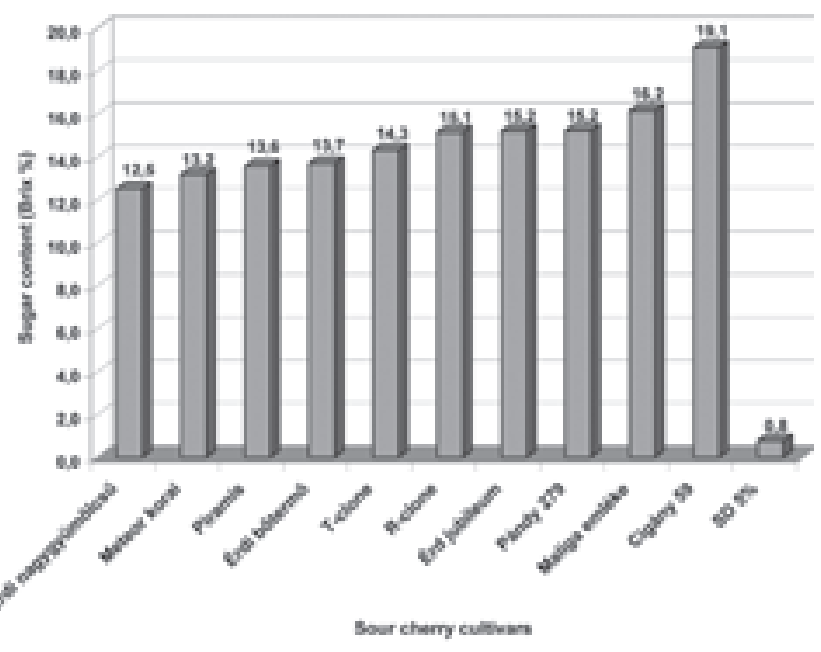

Figure 2: Total sugar content (Brix \%) of tested sour cherry varieties (2006)

Earlier Verner \& Blodget (1931) had that conclusion that fruit cracking was directly affected by the osmotic concentration of the fruit juice. In our trial we found cultivars ( 'Cigány 59', 'Pándey 279' " $T$ " and "R"-clones) with high sugar content and cracked less scale than others ('Érdi nagy gyümölcsü'; 'Meteor korai' and 'Piramis') with lover sugar content (based on data shown in Table 4 and Table 6). In contrast of Verner \& Blodget (1931) our results confirm Tucker's opinion that the sugar content is not correlation with the cracking tendency of cherry fruits (Tucker, 1934).

The fruit firmness and skin strength of tested varieties was measured by "QB-129" type fruit examinator. Fruits firmness (elasticity) was measured by destructive method when juice was coming out from fruits. There were found big differences of fruit firmness and skin strength of observed cultivars (Figure 3). Our results are only partly agreement with Christensen's (1996) opinion that cherry cultivars with firmer fruits are more prone to fruit cracking than softer ones. There were some varieties with firmer fruits ('Piramis' and 'Érdi nagygyümölcsü') and cracked in high proportion - it was in agreement with Christensen's (1996) opinion. Other cultivars like 'Érdi bőtermő' and 'Maliga emléke' had softer fruit firmness but depended to extremely cracking group (data shown in Figure 3 and Table 4). Also were verities with relatively high fruit firmness and cracked the least scale.

By this was seemingly we did not found close relationship between the fruit firmness and the cracking tendency of sour cherry fruits. It was based on one year results, further more trials are needed because this result is in contrast with Christensen's (1996).

Fruit weight changing during immersing in distillated water: We found that during fruits immersing in distillated water the fruit weight was increasing due to the absorbed water (Figure 4). We found varieties ('Maliga emléke', 'Piramis' and 'Érdi nagygyümölcsü') with low scale of fruit weight increasing (by water absorption) but these varieties were very susceptible to fruit cracking. Our opinion is that there is no close relationship between the scale of fruit cracking and the quantity of absorbed water. It was concluded by one year (2006) data more detailed studies on these data should be carried out in the future.

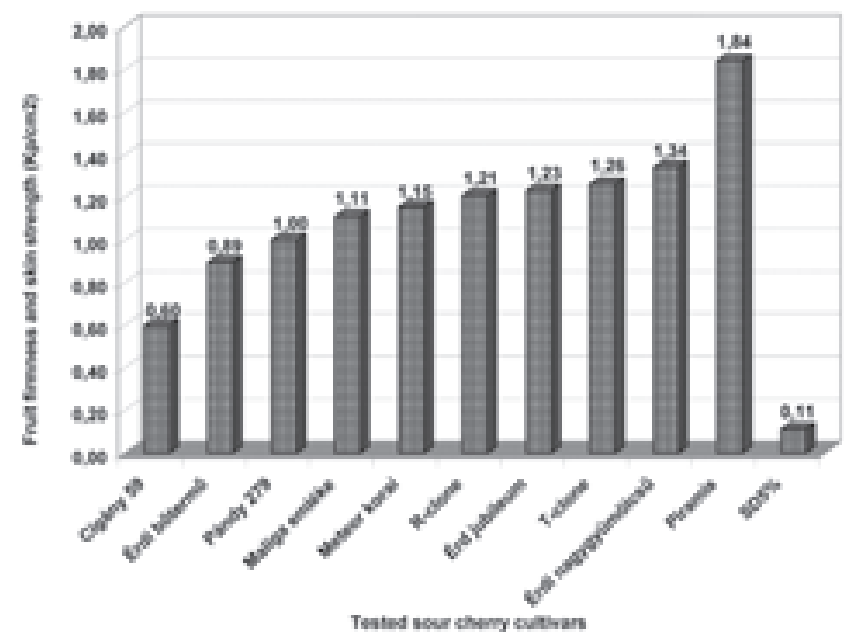

Figure 3: Fruit firmness and skin strength $\left(\mathrm{Kp} / \mathrm{cm}^{2}\right)$ of tested sour cherry varieties (2006)

Figure 4: Fruit weight changing (in \%) of sour cherries by immersing time in distillated water (2006).

\section{Sweet cherry}

For several years (1995-1998 and 1997-1998) total sugar content, fruit cracking after 4 and 24 hours and fruit firmness parameters were tested under laboratory conditions. The cracking percentage after 4 hours' dipping was higher with 'Germersdorfi'. The extraordinarily high cracking percentage $(54.5 \%$, three times higher than 'Germersdorfi') of 'Van' after 24 hours' dipping is worthy of note. This result can be explained by higher sugar content of 'Van' fruits. After long period (24 hours) immersion in water 'Van' fruits cracked 
in higher percentage because their osmotic concentration was significantly higher, and by this way their water uptake through the fruit skin was higher too. We could not find close relationship the fruit cracking and observed fruit parameters (Table 7). It was interesting that 'Van' cracked more seriously than 'Germesdorfi óriás'. It was in contrast with the literature (Apostol, 2003; Tóth, 2001).

Table 7: Fruit quality parameters and cracking ratio of 'Van' and 'Germesdorfi óriás' sweet cherry cultivars in average of different rootstocks. (Simon et al. 2004)

\begin{tabular}{|c|c|c|c|c|c|c|c|c|}
\hline \multirow{2}{*}{$\begin{array}{l}\text { Cultivar } \\
\text { Van }\end{array}$} & \multicolumn{2}{|c|}{$\begin{array}{l}\text { Sugar content } \\
\text { (Brix \%) } * *\end{array}$} & \multicolumn{2}{|c|}{$\begin{array}{c}\text { Fruit } \\
\text { cracking after } \\
4 \text { hours }(\%) \\
* *\end{array}$} & \multicolumn{2}{|c|}{$\begin{array}{c}\text { Fruit } \\
\text { cracking after } \\
24 \text { hours }(\%) \\
* * *\end{array}$} & \multicolumn{2}{|c|}{$\begin{array}{c}\text { Fruit } \\
\text { firmness } \\
\left(\mathrm{N} / \mathrm{cm}^{2}\right) * * *\end{array}$} \\
\hline & 18.20 & b & 2.13 & a & 54.52 & b & 2,62 & $\mathrm{a}$ \\
\hline $\begin{array}{l}\text { Ger- } \\
\text { mersdorfi } \\
\text { óriás }\end{array}$ & 17.58 & $\mathrm{a}$ & 7.11 & b & 17.48 & $\mathrm{a}$ & 3.14 & $\mathrm{~b}$ \\
\hline
\end{tabular}

** average of 4 years (1995-98) $\quad * * *$ average of 2 years (1997-98)

In 2006 three sweet cherry cultivars From Érd-Elvíra Gene bank were tested to fruit cracking under laboratory conditions. It was differences in the cracking ratio and the cracking dynamics of the tested sweet cherry cultivars when they were immersed in distillated water for 24 hours (Table 8).

It was found that the cracking ratio of very cracking susceptible sour cherry varieties had the same or higher cracking index than observed sweet cherries (data of 2. and 8. tables). It is in contrast with the general opinion (Christensen, 1996) that sour cherries are less prone to rain induced fruit cracking than sweet cherries.

Table 8: Cracking susceptibility (cracking ratio in \%) of the tested sweet cherry cultivars according to immersing time in distillated water (2006; source Simon 2010)

\begin{tabular}{|l|c|c|c|}
\hline \multirow{2}{*}{$\begin{array}{c}\text { Immersing } \\
\text { time }\end{array}$} & \multicolumn{3}{|c|}{$\begin{array}{c}\text { Sweet cherry cultivars } \\
\text { Cracking ratio in \% }\end{array}$} \\
\cline { 2 - 4 } & 'Germersdorfi 3.' & 'Katalin' & 'Kavics' \\
\hline 0 hour & 0,0 & 0,0 & 0,0 \\
\hline $\mathbf{2}$ hours & 0,0 & 0,0 & 0,0 \\
\hline $\mathbf{4}$ hours & $13,3 \%$ & 0,0 & $10,0 \%$ \\
\hline 6 hours & $29,2 \%$ & $5,0 \%$ & $12,0 \%$ \\
\hline $\mathbf{8}$ hours & $44,2 \%$ & $10,0 \%$ & $16,0 \%$ \\
\hline $\mathbf{1 0}$ hours & $49,2 \%$ & $26,0 \%$ & $20,0 \%$ \\
\hline $\mathbf{1 2}$ hours & $54,2 \%$ & $39,0 \%$ & $51,0 \%$ \\
\hline $\mathbf{1 8}$ hours & $85,0 \%$ & $70,0 \%$ & $83,0 \%$ \\
\hline $\mathbf{2 4}$ hours & $85,0 \%$ & $77,0 \%$ & $93,0 \%$ \\
\hline
\end{tabular}

Cracking ratio and cracking dynamic by the water immersing time were tested on 'Katalin' cherry fruits in 2013. In contrast of 2006 year (Table 8.) we found that intensive cracking earlier in the $2-3$ hour. By the $5^{\text {th }}$ hour the ratio of cracked fruits reached the $35 \%$. From the $10^{\text {th }}$ to the $20^{\text {th }}$ hour it was very slow increasing in the ratio of cracked fruits. Later it was an intensive increasing again (Figure 5). It can be see that there is a difference between the cracking ration

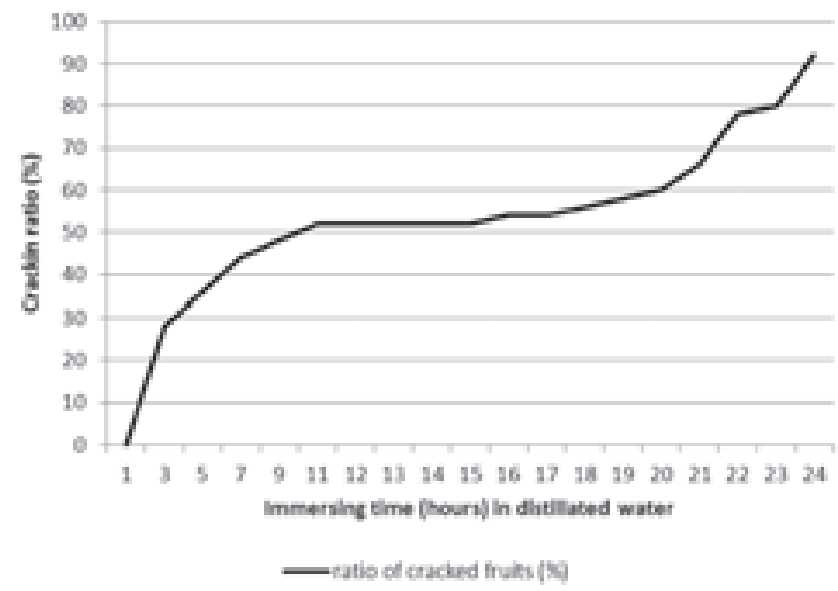

Figure 5: Ratio (in \%) of cracked 'Katalin' sweet cherry cv. by immersing time in distillated water (2013, Törökbálint)

and cracking dynamic of the same cultivar in different years. It is in agreement Pennel and Webster's (1996) opinion that the year effect cause big differences in the fruit cracking of cherries.

\section{European plums}

In some years can be hear problems on the rain induced fruit cracking of European plums too (Rémy et.al. 1992).

Fruit cracking tests of European plum cultivars under laboratory conditions (fruits were immersed in distillated water): We found differences in the cracking ratio and the cracking dynamics of the tested plum varieties when they were immersed in distillated water for 24 hours (data are shown in Table 9 and Figure 6).

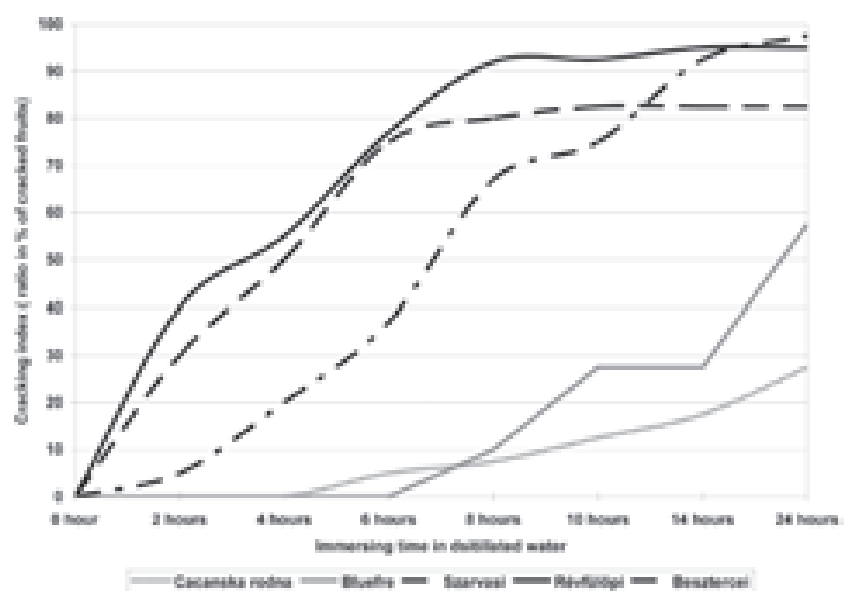

Figure 6: Cracking susceptibility (cracking ratio in \%) of the tested European plum cultivars status according to immersing time in distillated water (2006, Agárd)

By data of Table 9 and Figure 6 there are significant differences in cracking susceptibility between tested the European plum cultivars. The homogene groups are signed with letters by immersing time (horizontal).

After 6 hours immersing in water it were found that varieties can be divided three groups by their cracking sus- 
Table 9: Cracking index (\% of cracked fruits) of fresh market ripped European plums 2006

\begin{tabular}{|c|c|c|c|c|c|c|c|c|c|c|}
\hline & \multicolumn{2}{|c|}{ Cacanska rodna } & \multicolumn{2}{|c|}{ Bluefre } & \multicolumn{2}{|c|}{ Szarvasi } & \multicolumn{2}{|c|}{ Révfülöpi } & \multicolumn{2}{|c|}{ Besztercei } \\
\hline & $\begin{array}{c}\text { Cracking } \\
\% \\
\end{array}$ & $\begin{array}{l}\text { Homogene } \\
\text { group }\end{array}$ & $\begin{array}{c}\text { Cracking } \\
\% \\
\end{array}$ & $\begin{array}{c}\text { Homogene } \\
\text { group }\end{array}$ & $\begin{array}{c}\text { Cracking } \\
\% \\
\end{array}$ & $\begin{array}{l}\text { Homogene } \\
\text { group }\end{array}$ & $\begin{array}{c}\text { Cracking } \\
\% \\
\end{array}$ & $\begin{array}{c}\text { Homogene } \\
\text { group }\end{array}$ & $\begin{array}{c}\text { Cracking } \\
\% \\
\end{array}$ & $\begin{array}{c}\text { Homogene } \\
\text { group }\end{array}$ \\
\hline 0 hour & $\mathbf{0}$ & $\mathrm{a}$ & 0 & $\mathrm{a}$ & $\mathbf{0}$ & $\mathrm{a}$ & $\mathbf{0}$ & $\mathrm{a}$ & $\mathbf{0}$ & $\mathrm{a}$ \\
\hline 2 hours & $\mathbf{0}$ & $\mathrm{a}$ & $\mathbf{0}$ & $\mathrm{a}$ & 30 & $\mathrm{~b}$ & 40 & $\mathrm{~b}$ & 5 & $\mathrm{a}$ \\
\hline 4 hours & $\mathbf{0}$ & $\mathrm{a}$ & $\mathbf{0}$ & $\mathrm{a}$ & 50 & $\mathrm{c}$ & 55 & $\mathrm{c}$ & 20 & $\mathrm{~b}$ \\
\hline 6 hours & 5 & $\mathrm{a}$ & $\mathbf{0}$ & $\mathrm{a}$ & 75 & $\mathrm{c}$ & 77 & $\mathrm{c}$ & 37 & $\mathrm{~b}$ \\
\hline 8 hours & 7,5 & $\mathrm{a}$ & 10 & $\mathrm{a}$ & 80 & $\mathrm{bc}$ & 92 & $\mathrm{c}$ & 67 & $\mathrm{~b}$ \\
\hline 10 hours & 12,5 & $\mathrm{a}$ & 27,5 & $\mathrm{~b}$ & 82,5 & $\mathrm{bc}$ & 92,5 & $\mathrm{c}$ & 75 & $\mathrm{~b}$ \\
\hline 14 hours & 17,5 & $\mathrm{a}$ & 27,5 & $\mathrm{a}$ & 82,5 & $\mathrm{~b}$ & 95 & $\mathrm{~b}$ & 92,5 & $\mathrm{~b}$ \\
\hline 24 hours & 27,5 & $\mathrm{a}$ & 57,5 & $\mathrm{~b}$ & 82,5 & $\mathrm{c}$ & 95 & $\mathrm{c}$ & $\mathbf{9 7 , 5}$ & $\mathrm{c}$ \\
\hline
\end{tabular}

ceptibility: „Very susceptible”: 'Révfülöpi' and 'Szarvasi'; „Susceptible”: 'Besztercei'; „Less sensitive”: 'Bluefre' and 'Cacanska rodna'.

After 24 hours immersing in water it were only two groups with significant differences: „Susceptible group”: 'Révfülöpi', 'Szarvasi' and 'Besztercei'; „Less sensitive”: 'Bluefre' and 'Cacanska rodna'

GardenWeb (2011) presented an information about cracking indexes of European and Asian type plums (mainly about Asian type plums) and categorized cultivars in Very High ( $>60 \%$ crack or bad); High (40-60\% cracked); Medium (20-40\% cracked fruits); Low (10-20\%); Very Low (less then $10 \%$ ).

The average fruit weight: The average fruit weight of plum cultivars was calculated by 10 fruits repeated 4 times. Calculated average fruit weights of the samples are shown in the Figure 7.

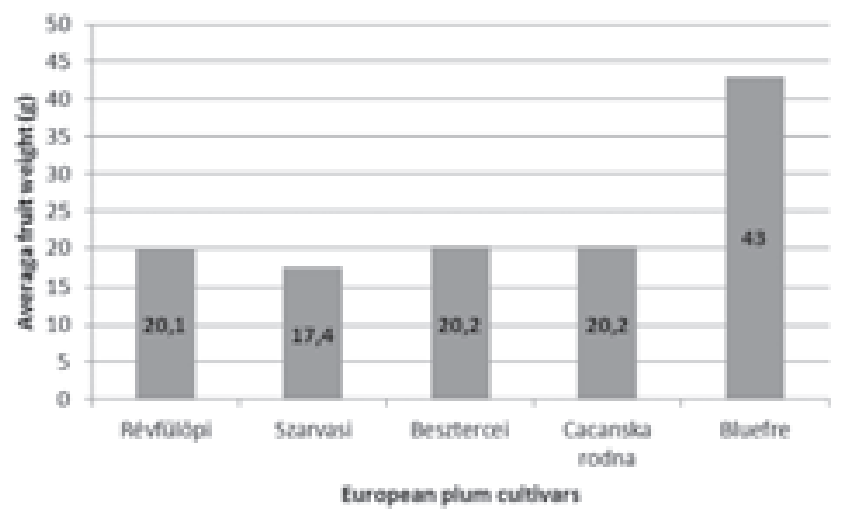

Figure 7: Average fruit weight of tested European plum cultivars (2006, Agárd)

We found that the average fruit weight of tested European plum (except cv 'Besztercei') cultivars was lower than in the literature (Brózik and Kállayné 2001; Szabó 2003, 2004). The reasons of the fruit size degradation are the followings: the orchard was virus infected, the last pruning was 3-4 years ago, growing without irrigation.

Similarly the cherries we did not find correlation between the fruit size and cracking susceptibility of European plum cultivars. It was based on: the big fruit sized 'Bluefre' and middle sized 'Cacanska rodna' cracked in the lowest scale, during the small sized 'Révfülöpi', 'Szarvasi' and 'Besztercei' cultivars cracked in higher scale (Figure 6 and 7).

\section{Total sugar content (Brix\%):}

We found positive correlations between the cracking susceptibility and total sugar content (Brix\%) of tested plum cultivars. Cultivars with significantly lower sugar content ('Bluefre' and 'C. rodna') showed lower fruit cracking susceptibility than cultivars ('Révfülöpi', 'Szarvasi' and 'Besztercei') with higher sugar content (Figure 6 and 8).

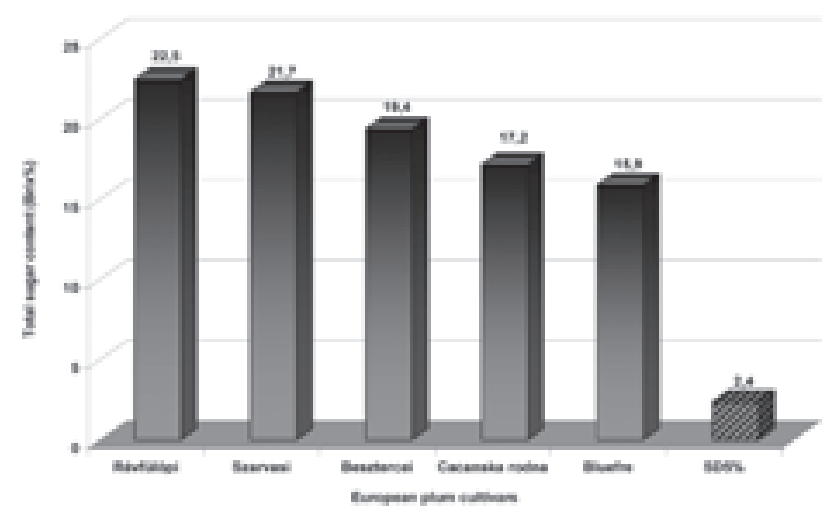

Figure 8: Total sugar content (Brix\%) of tested European plum cultivars (2006, Agárd

Fruit skin strength of tested European plum cultivars:

Similarly the cherries we did not find correlation between the skin strength and cracking susceptibility of European plum cultivars. It was based on that fruit skin strength data of 'Szarvasi'-'Révfülöpi'-'Besztercei'-'Cacanska rodna' cultivars were no significantly different but the ' $C$. rodna' shoved dramatically lower cracking susceptibility than the other three.

Fruit weight changing of plum fruits during immersing in distillated water: We found that during fruits immersing in distillated water the fruit weight was increasing due to the absorbed water (Figure 9). We found close relationship between the relative (\%) absorbed water amount and the fruit cracking susceptibility (Figure 6 and 9). Cultivars with higher absorbed water amount ('Szarvasi'-'Révfülöpi''Besztercei') had higher cracking susceptibility. 


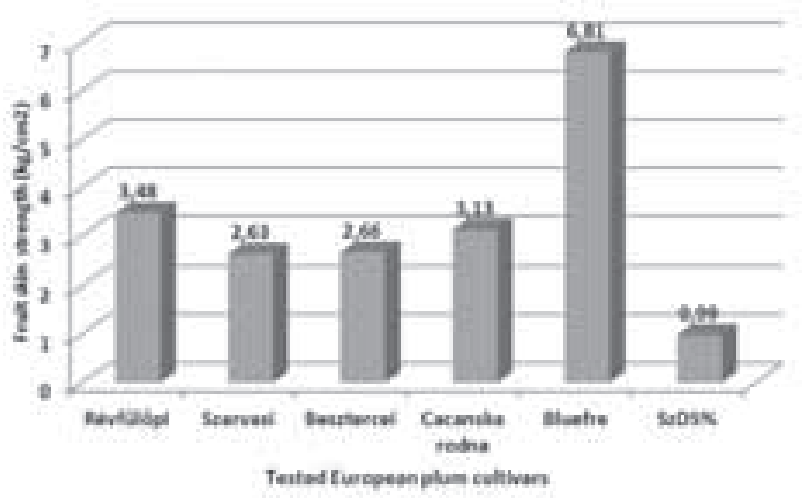

Figure 9: Fruit skin strength of tested European plum cultivars (2006, Agárd)

Pictures of cracked fruits and the immersing process are showed in the chapter Supplements.

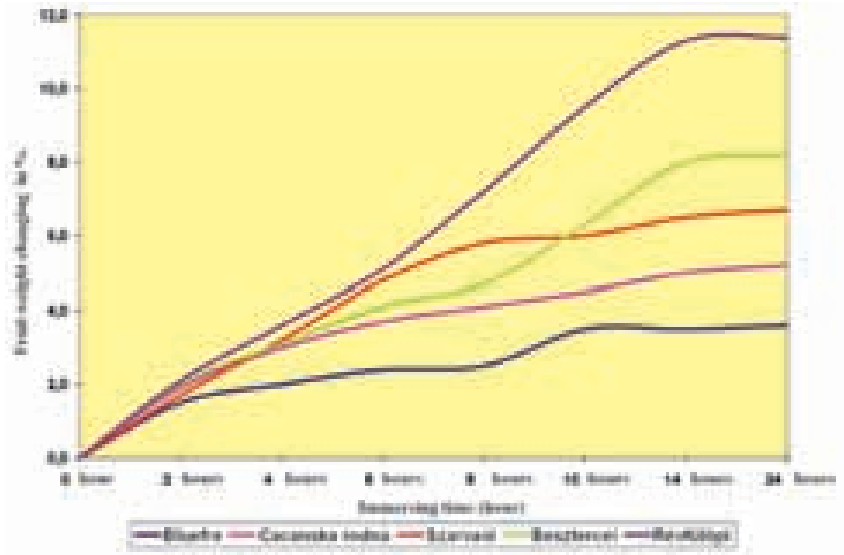

Figure 10: Fruit weight changing (in \%) of European plum cultivars by immersing time in distillated water (2006, Agárd)

\section{Supplements}

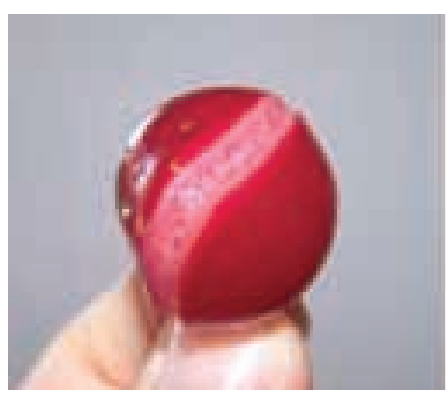

1 supplement:

Cracked 'Pándy 279' fruit

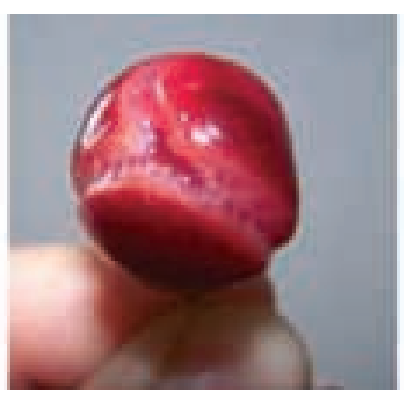

2 supplement:

Cracked 'Cigány59' fruit

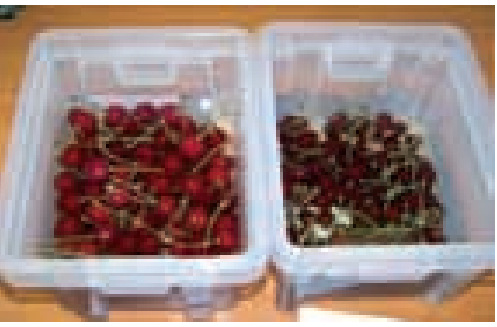

4 supplement:

Immersing of sour cherries

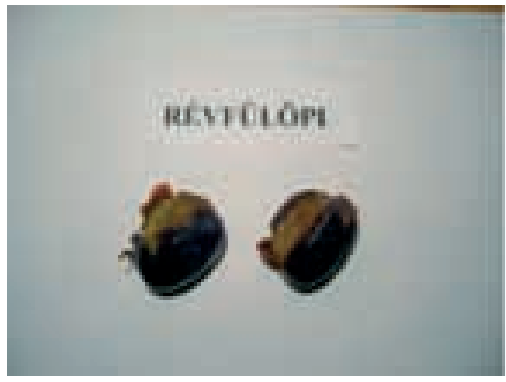

5 supplement:

Cracked 'Révfülöpi' fruit

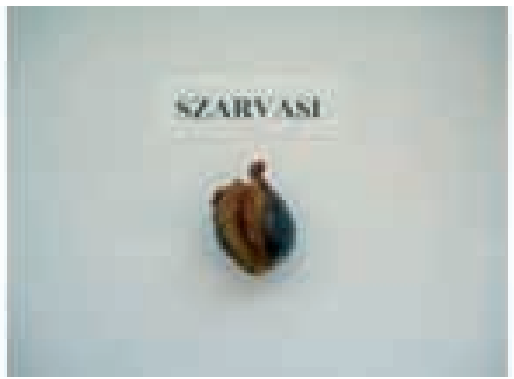

6 supplement: Cracked Szarvasi' fruit

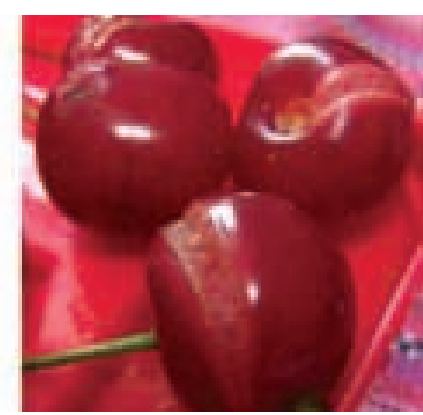

3 supplement:

Cracked „T"'-clone fruit

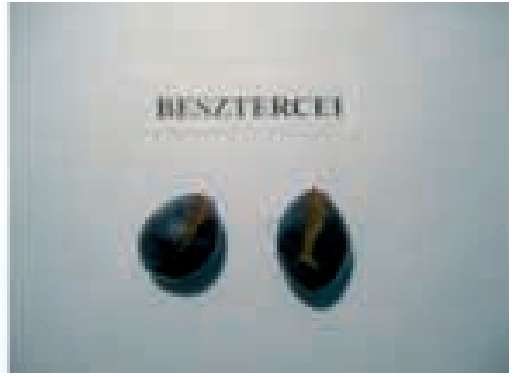

7 supplement:

Cracked 'Besztercei' fruit 


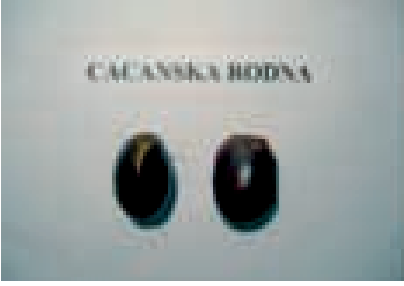

8 supplement: :

Cracked 'C. rodna' fruit

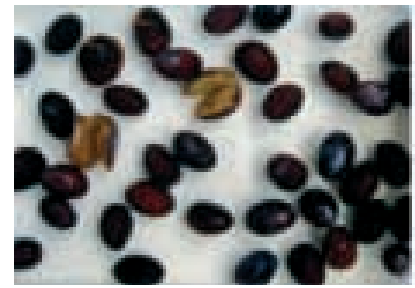

10 supplement:

'Cacanska rodna' after 24 hours immersing

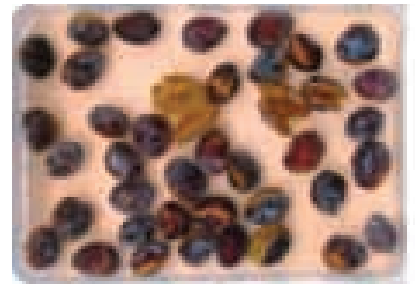

12 supplement:

'Beszercei' after 24 hours immersing

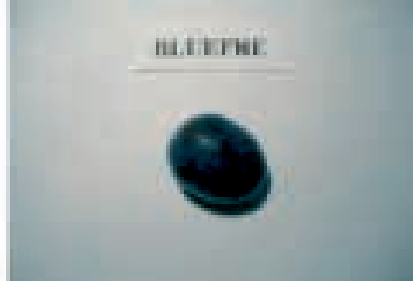

Cracked 'Bluefre' fruit

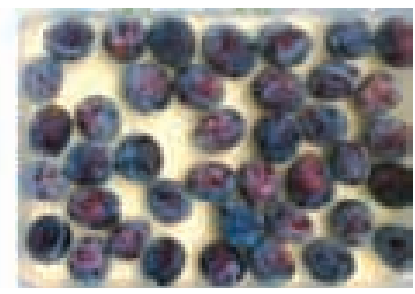

11 supplement: 'Bluefre' after 24 hours immersing

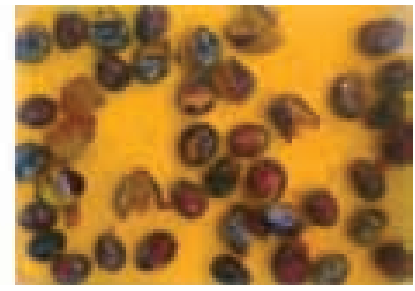

13 supplement:

'Szarvasi' after 24 hours immersing
9 supplement:

\section{References}

Apostol, J. (2003): Cseresznye- és meggynemesítés, a fontosabb fajták leírása. [In Hrotkó, K. (szerk): Cseresnye és meggy.] Mezőgazda Kiadó, Budapest, 37-95.

Brózik S. \& Kállay T.-né (szerk.), 2001: Gyümölcsfajták 2. Csonthéjas és héjas gyümölcsfajták, Mezőgazda Kiadó, Budapest

Christensen J.V. (1975): Cracking in Cherries VII. Cracking susceptibility in relation to fruit size and firmness. Acta Agriculturae Scandinavica 25: 301-312.

Christensen J.V. (1996): Rain-induced fruit cracking of sweet cherries: Its causes and prevention. [In A.D. Webster and N.E. Looney (eds) Cherries: Crop Physiology, Production and Uses.] Cab International, UK. 297-327.

GardenWeb (2011): Plum Cracking. http://forums2.gardenweb. com/forums/load/fruit/msg0114500926155.html (2014.05.04.)

Pennel D. \& A.D. Webster (1996): Protection of fruit from Damage. in ed: Webster, S.D. \& Looney, N.E. (1996): Cherries: Crop Physiology, Production and Uses. Cab International, UK.
Rémy E. Milad and Kenneth A. Shackel (1992): Water Relations of Fruit End Cracking in French Prune (Prunus domestica L. cv. French) J. AMER. SOC. HORT. SCI. 117 (5): 824-828.

Sekse, L. (1987): Fruit cracking [in Norwegian grown sweet cherries.] Acta Agriculturae Scandinavica 37: 325-328.

Simon G., Hrotkó K. and Magyar L. (2004): Fruit Quality of Sweet Cherry Culticars Grafted on Four Different Rootstocks. International Journal of Horticultural Science. 10 (1): 59-62.

Simon, G. (2006) Review of the rain induced frit cracking of sweet cherries (Prunus avium L.) and its causes and the possibilities of prevention. International Journal of Horticultural Science, 12 (3): 27-35.

Simon, G., Tóth, M. \& Papp, J. (2007): Cracking susceptibility of sour cherry (Prunus cerasus L.) in Hungary and relation to calcium application. International Journal of Horticultural Science, 13 (3): 109-118.

Simon G. (2010) „Inhibition techniques of rain induced fruit cracking of cherries" habilitation oral presentation. 2010.05.10. Corvinus University of Budapest, Buda Campus (Unpublished data of Germersdorfi óriás, Katalin and Kavics cherry cultivars cracking indexes in 2006, Érd-Elvíra)

Soltész M. (szerk.), 1998: Gyümölcsfajta- ismeret és -használat, Mezőgazda Kiadó, Budapest. 513. p.

Szabó Z. (1997): Szilva [in: Soltész M. (szerk.), Intergrált gyümölcstermesztés, Mezőgazda Kiadó, Budapest, 600-619.

Szabó Z. (2003): Szilva [in: G. Tóth M. (szerk.) Gyümölcsészeti jegyzetek, Jegyzet] 81-91, Budapesti Közgazdaságtudományi és Államigazgatási Egyetem Kertészettudományi Kar, Budapest

Szabó Z. (2004): Szilva [in: Papp J. (szerk.) A gyümölcsök termesztése.] Mezőgazda Kiadó, Budapest, 235-263.

Tóth E., Surányi D., Erdős Z. (2005): A szilvafajták szelekciója és új eredményei Cegléden [In Tóth M. (ed.) A fajtaválaszték fejlesztése a kertészetben] Kertgazdaság Horticulture Különkiadás, Budapest, 67-78.

Tóth M. (2001): Csresznye [In. Tóth M. (ed.) Gyümölcsészet] Primom Sz-Sz-B. Megyei Vállakozásélénkítő Alapítvány Vállalkozói Központ. 243-288.

Tóth M., Simon G. (2009): Cseresznye. [In: Tóth M. (szerk.) Gyümölcs faj és faj- és fajtaismeret egyetemi jegyzet.] Budapesti Corvinus Egyetem Kertészettudományi Kar, 85-102.

Tucker R. (1934): A varietal study of the susceptibility of sweet cherries to cracking. University of Idaho Agriculture Experimental Station Bulletin 211: 1-15.

Verner, L. \& Bodget, E,C. (1931): Physiological studies $f$ the cracking of sweet cherries. University of Idaho Agriculture Experimental Station Bulletin No. 184.

Zielinski, B.Q. (1964): Resistance of sweet cherry varieties to fruit cracking in relation to fruit and pit size and fruit colour. Proceedings of the American Society for Horticultural Science 84: 98-102. 